\title{
Genetic Diversity Analysis in Sub-tropical Maize (Zea Mays L.) germplasm
}

\author{
HabiburahmanAyoubi ${ }^{* 1}$, Shailesh Marker ${ }^{2}$, Gideon J. Synrem ${ }^{3}$ and \\ L.Naresh $\mathrm{Kumar}^{4}$ \\ ${ }^{* 1}$ (M.Sc. student Dept. of Genetics and Plant Breeding, SHIATS, Allahabad, India) \\ ${ }^{2}$ (Prof. Dept. of GPB, SHIATS, Allahabad, India) \\ ${ }_{3,4}$ (Ph. D Scholar Dept. of Genetics and Plant Breeding, SHIATS, Allahabad, India \\ Department of Genetics and Plant Breeding,Sam Higginbottom Institute of Agriculture, Technology \& Sciences, \\ Allahabad - 211007 INDIA
}

\begin{abstract}
The present investigation was conducted to examine the genetic diversity existing among 50 genotypes of maize, during Rabi-2014sown under randomized block design with three replications. The data were recorded for sixteen quantitative characters to obtain estimates of variability, heritability, genetic advance and genetic divergence. Significant differences were observed among the genotypes for all the characters studied except for number of cobs per plant. High estimates of GCV and PCV were observed for leaf area indexfollowed by leaf area per plant and number of grains per row. High heritability coupled with high genetic advance was recorded for leaf area per plant and plant height. Mahalanobis $D^{2}$ analysis revealed considerable amount of diversity in the material. The 50genotypes were grouped into 8 heterogeneous clusters. Among these clusters, Cluster Ihad maximum number of genotypes (14 genotypes).On the basis of mean performance genotypesHKI 193-1-1, R-13-1, TARUN 83-1-32, R-13-1-17 was found to be the best genotypes in Allahabad agro-climatic conditions. The characters such as leaf area per plant, plant height, days to $50 \%$ tasseling, days to $50 \%$ silking, seed fill duration and cob height showed high heritability coupled with moderate genetic advance which indicates that there is more chance of inheritance from progeny to their offspring, therefore these characters should be given top priority for effective selection. The present investigation revealed that ClusterVI and VIIIwere most diverse.Genotypes constituted in these clusters may be used as parents for future hybridization.
\end{abstract}

Keywords:Maize (Zea mays L.), $D^{2}$ analysis and genetic diversity.

\section{Introduction}

Maize (Zea mays L.) is one of the most important cereal crops and has the highest production area worldwide followed by wheat and rice (FAO 2012) due to its diverse usage and being a staple food to large number of human population in the world. It plays a significant role in human and livestock nutrition worldwide and has greater nutritional value, as it contains about $72 \%$ starch, $10 \%$ proteins, $8.5 \%$ fibre, $4.8 \%$ oil, $3 \%$ sugar and $1.7 \%$ ash, (Chaudhry, 1983). It is the highest yielding grain crop having multiple uses and one of the most important cereal crops and occupies prominent position in global agriculture after wheat and rice (Seshuet al, 2014). Theidentification of genetically distant parental combinations provides better crop improvement strategy for breeders. $\mathrm{D}^{2}$ analysis is a useful tool for quantifying the degree of divergence between biological population at genotypic level and in assessing relative contribution of different components to the total divergence both in intra and inter-cluster level (Murty and Arunachalam, 1966, Ram and Panwar, 1970, Sachan and Sharma, 1971).

\section{Materials And Methods}

The present study was conducted in the Field Experimentation Centreof the Department of Genetics and Plant Breeding, Allahabad School of Agriculture, Sam Higginbottom Institute of Agriculture, Technology and Sciences. They were raised in randomize block design (RBD) with three replications. Observations were recorded for Days to $50 \%$ tasseling, Days to $50 \%$ silking, Anthesissilking interval, Seed fill duration, Days to maturity, Plant height $(\mathrm{cm})$, Cob height $(\mathrm{cm})$, Number of cobs per plant, Cob length $(\mathrm{cm})$, Cob girth $(\mathrm{cm})$, Grain rows per cob, Kernels per row, Grain yield per plant (g), 100 seed weight, Leaf area per plant and Leaf area index. The data were analysed by using analysis of variance suggested by Panse\&Sukhatme (1964), genetic divergence was estimated by using $\mathrm{D}^{2}$ statistics of Mahalanobis (1936) and clustering of genotypes was done according to Tocher's method as described by Rao (1952). The percent contribution of characters towards genetic divergence was calculated according to Singh \&Chaudhary(1985). 


\section{Results And Discussion}

The analysis of variance revealed highly significant differences among the genotypes for all the 16 characters except for number of cobs per plant indicating the existence of genetic variability among the experimental material. The 50 genotypes of maize were grouped into eight clusters, the composition of which is presented in Table1. Cluster I was the largest having 14 genotypes indicating genetic similarity among them, whereas cluster VI (9 genotypes), cluster II and VIII (7 genotypes), cluster V (6 genotypes), cluster III and VII (3 genotypes), and clusterIV had one genotype. The intra- and inter-cluster values among the eight clusters are presented in Table 2. The intra-cluster distances were lower than the inter-cluster distances. Thus, the genotypes included within a cluster had less diversity among themselves. The maximum intra-cluster distance (3496.39) was observed in cluster VIII followed by cluster VII (3451.88), cluster III (2757.59), cluster I (1984.62) and cluster IV (1964.37). The highest inter-cluster distance (25678.40) was observed between clusters VI and VIII followed by clusters VI and VII (24302.36), clusters II and VII (21519), II and VIII (20345.52), clusters II and IV (18440.41), clusters I and VIII (18179.26) and clusters II and VI (15878.48), suggesting more diversity in genetic make-up of the genotypes included in these clusters VI, VIII, VII, II, IV and I (Fig. 1). The genotypes belonging to the clusters separated by high statistical distance could be used in hybridization programme for obtaining a wide spectrum of variation among the segregates. In this context, genotypes from cluster VI, VIII, VII, II, IV and I should be selected as parents in hybridization programme for yield improvement in genotypes of maize. These findings are in conformity with the similar findingsof Singh and Chaudhari (2001), Datta and Mukherje (2004) and Marker and Krupakar (2009). The cluster means of 16 characters are presented in Table 3. Greatest range of mean values among the clusters was recorded for different traits. Cluster VII recorded highest mean values for leaf area per plant (8936.67), number of kernels per row (35.40), ear length (15.00) with minimum days to $50 \%$ tasseling (67.33), days to 50\% silking (70.66) and days to maturity (98.33). Cluster VI was the second highest for grain yield per plant (72.62) with high number of kernel rows per ear (15.80), ear girth (14.79), ear height (84.93) and plant height (185.93), while the cluster IV (27.03) had high mean value for 100-seed weight. The results were well supported by similar findings by Synremet al. 2015andAmin et al . (2013) and Reddy et al. (2013)whoreported number of kernels per row, ear length, kernel yield, days to pollen shedding and yield per plant contributed maximum towards total divergence.

\section{Conclusion}

It is concluded that genotypes HKI-193-1-1, R-13-1, TARUN 83-1-32 and R-13-1-17 were found superior in terms of yield production as well as for other important yield contributing traits. In general PCV values were higher than GCV values, which indicate the effect of environment on the expression of these characters. Leaf area per plant and plant height recorded high estimates for heritability and genetic advance. The maximum inter-cluster $\mathrm{D}^{2}$ value was observed between cluster VI and VIII $(25678.40)$ followed by distance between cluster VI and VII (24302.36) and between cluster II and VII (21519.34), suggesting that the inbred lines belonging to these clusters may be used as parents for future hybridization program to exhibit high heterosis with recombinants of desired characters in maize, since crosses between genetically divergent inbred lines will generate heteroticsegregants. As heterosis can be best exploited and chances of getting trangressivesegregants are maximum, when selection of diverse lines are crossed among them.

\section{Acknowledgement}

The Authors are sincerely grateful to the Hon'ble Vice-Chancellor, Sam Higginbottom Institute of Agriculture, Technology and Sciences, Allahabad, for providing the necessary facilities for completing the research work.

\section{References}

[1]. Chaudhry, A. R.Maize in Pakistan. PunjabAgriculture Research, Coordination Board, University of Agriculture., Faisalabad Pakistan 1983, 312-317.

[2]. Seshu, G., Rao, B.M.V., Sudarshan, M. R. and Eeswari, K. B.Genetic divergence in Sweet Corn (ZeamaysL. saccharata.) Internatinal Journal of Pure and Applied Bioscience 2 (1), 2014, 196-201.

[3]. Murty, B. R. and Arunachalam, V.The nature of divergence in relation to breeding system in crop plants Indian Journal of Genetics, 26, 1966, 188-198

[4]. Ram, J. and Panwar, D. V. S. Interspecific divergence in rice (OryzaSaativa L.)Indian Journal of Genetics,30, $1970,1-2$.

[5]. Sachan, K. S. and Sharama. G. R.Multivariate analysis of divergence in tomato Indian Journal of Genetics,31, 1971, 86-93.

[6]. Panse, V.G. and Sukhatme, P.V.Statistical methods for Agricultural workers. ICAR, New Delhi, pp. 1964,235-247.

[7]. Mahalanobis, P.C.On generalized distance in statistics. Proceedings of National Institute of Science 2, 1936, 49-55.

[8]. Rao, C.R.Advanced statistical method in biometrical Research. J. Wiley and Sons ,Inc. New York. 15 (10), $1952,130-134$.

[9]. Singh, R.K. and Chaudhary, B.D.Biometrical methods in quantitative genetic analysis, Kalyani publishers, New Delhi-Ludhiana, India.1985, pp.318.

[10]. Singh, P. K. and Chaudhari, L. B.Genetic divergence in maize (Zea mays L.) Journal of Research BirsaAgriculture University.13, 2001, 193-195. 
[11]. Datta, D. and Mukherjee, B. K.Genetic divergence among maize (Zea mays L.) inbreds and restricting traits for group constellation. Indian Journal of Genetics and Plant Breeding64, 2004, 201-207.

[12]. S. Marker and A. KrupakarAdaptive responses and Genetic Divergence in local races of Maize. Annals of Plant and Soil Research 10 (1): 2008, 36-38.

[13]. Synrem, J., Marker, S., Bhusal, T. N. and Kumar, L.Genetic diversity for grain yield and physiological traits in maize (Zea mays L.). Geobios42, 2015,22-32.

[14]. Amin, M. N., Amiruzzaman, M., Ahmed, A., Rohman, M.M., and Ali M. R. The genetic diversity of white inbred lines of quality protein maize (QPM). Eco-Friendly Agricultural Journal 6(9), 2013,193-198.

[15]. Reddy, S. M., Kumar, S. S., Sudharshan, M. R. and Kumar, K. V. Genetic Divergence in Baby Corn (Zea Mays L.). International Journal of Innovative Research and Development 2(8), 2013, 300-304.

Table 1.Grouping of 50 maize (Zea mays L.)genotypes into different clusters

\begin{tabular}{|l|l|l|l|}
\hline S. No. & Cluster numbers & Number of genotypes & Genotypes Included \\
\hline 1 & I & 14 & $\begin{array}{l}\text { Tarun-1-2-3,HKI-193-2, DMR-N21,S99S-T4QBBB-3BBB, CML-304, } \\
\text { DMR-9071, CML-27, HY10RN-10235-4, DMR-9047, UMC-4, UMC-12, } \\
\text { TSK-194, R-13-1-1, R-13-1-17. }\end{array}$ \\
\hline 2 & II CML-358, CML-359,CML-224-1, \\
& & 7 & $\begin{array}{l}\text { CML470, CML-224, } \\
\text { YHPPANTH(PLOT 712), CML-439 }\end{array}$ \\
\hline 3 & III & 3 & YHPPANTH(PLOT 713), JP25 W95, Early Yellow. \\
\hline 4 & IV & 1 & POP-31Q \\
\hline 5 & V & 6 & $\begin{array}{l}\text { CML-165-HMT, HKI 34(H2)-1, CM-13, LM-13(PLOT 714), Tarun 83-1- } \\
\text { 32, CM-138 }\end{array}$ \\
\hline 6 & VI & 9 & $\begin{array}{l}\text { Vivek33VF2, EC-598475, NDUM2, CML-40, HY10RN-10235-274, IC- } \\
381506, \text { AP-407-F, TSK-197, R-13-1/10 }\end{array}$ \\
\hline 7 & VII & 3 & $\begin{array}{l}\text { HKI 193-1-1, CM-600, TSK-196. } \\
\text { 462, HY10RN-10235-105, CML-44. }\end{array}$ \\
\hline 8 & VIII & 7 &
\end{tabular}

Table 2.Average inter \& intra Cluster $\mathrm{D}^{2}$ value among the cluster for 50 maize (Zea mays L.) inbred lines

\begin{tabular}{|l|l|l|l|l|l|l|l|l|}
\hline Clusters & I & II & III & IV & V & VI & VII & VIII \\
\hline I & $\mathbf{1 9 8 4 . 6 2}$ & 8904.00 & 4618.17 & 5474.89 & 5143.27 & 4314.97 & 15546.02 & 18179.26 \\
\hline II & & $\mathbf{0 . 0 0}$ & 9404.85 & 18440.41 & 14534.17 & 15878.48 & 21519.34 & 20345.52 \\
\hline III & & & $\mathbf{2 7 5 7 . 5 9}$ & 6715.72 & 3353.14 & 11043.59 & 7771.76 & 10156.58 \\
\hline IV & & & & $\mathbf{1 9 6 4 . 3 7}$ & 2869.27 & 5582.41 & 11417.89 & 12749.68 \\
\hline V & & & & & $\mathbf{1 1 1 0 . 4 6}$ & 9136.35 & 5816.16 & 8466.64 \\
\hline VI & & & & & & $\mathbf{1 6 9 1 . 0 7}$ & 24302.36 & 25678.40 \\
\hline VII & & & & & & & $\mathbf{3 4 5 1 . 8 8}$ & 5854.65 \\
\hline VIII & & & & & & & & $\mathbf{3 4 9 6 . 3 9}$ \\
\hline
\end{tabular}

Table 3 Per cent contribution of different quantitative characters to genetic diversity in maize (Zea mays L.).

\begin{tabular}{|l|l|l|l|}
\hline S.NO & Source & Times Ranked 1st & Contribution \% \\
\hline 1 & Days to 50 \% tasseling & 0 & 0.00 \\
\hline 2 & Days to 50 \% silking & 0 & 0.00 \\
\hline 3 & Anthesissilking interval & 0 & 0.00 \\
\hline 4 & Seed fill duration & 2 & 0.16 \\
\hline 5 & Plant height & 0 & 0.00 \\
\hline 6 & Cob height & 328 & 26.78 \\
\hline 7 & Number of cobs per plant & 6 & 0.49 \\
\hline 8 & Days to maturity & 0 & 0.00 \\
\hline 9 & Cob length & 0 & 0.00 \\
\hline 10 & Cob girth & 0 & 0.00 \\
\hline 11 & Number of grain rows per cob & 0 & 0.00 \\
\hline 12 & Number of grains per row & 46 & 3.76 \\
\hline 13 & Grain yield per plant & 177 & 14.45 \\
\hline 14 & 100 seed weight & 7 & 0.57 \\
\hline 15 & Leaf area /Plant & 656 & 53.55 \\
\hline 16 & Leaf area index & 3 & 0.24 \\
\hline
\end{tabular}


Tocher Method

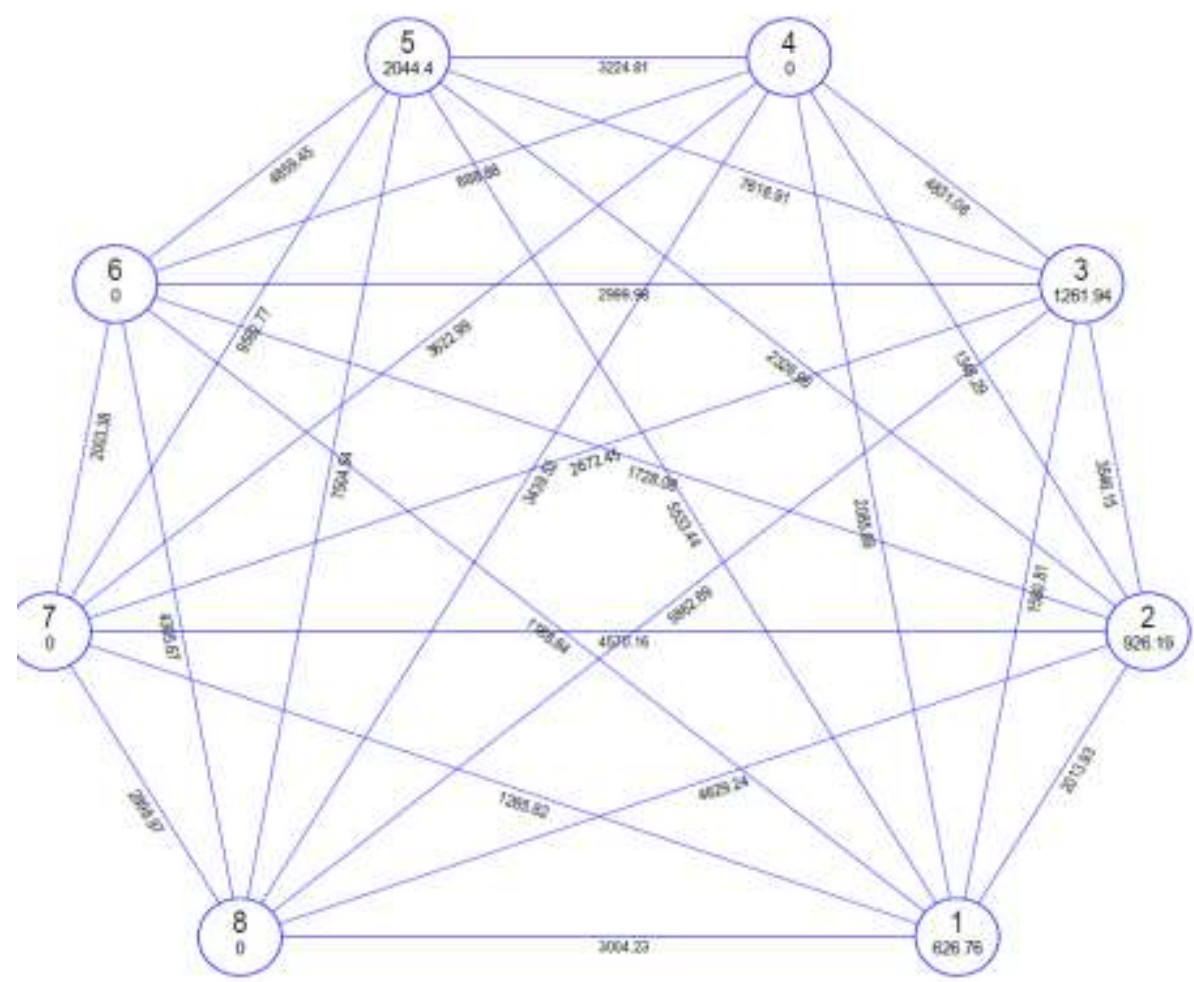

Mahalnobis Euclidean Disatnce (Not to the Scale)

Figure1.Intra and inter-cluster distance diagram for different quantitative and physiological characters in maize. Mahalanobis Euclidean Distance (Not to the Scale)

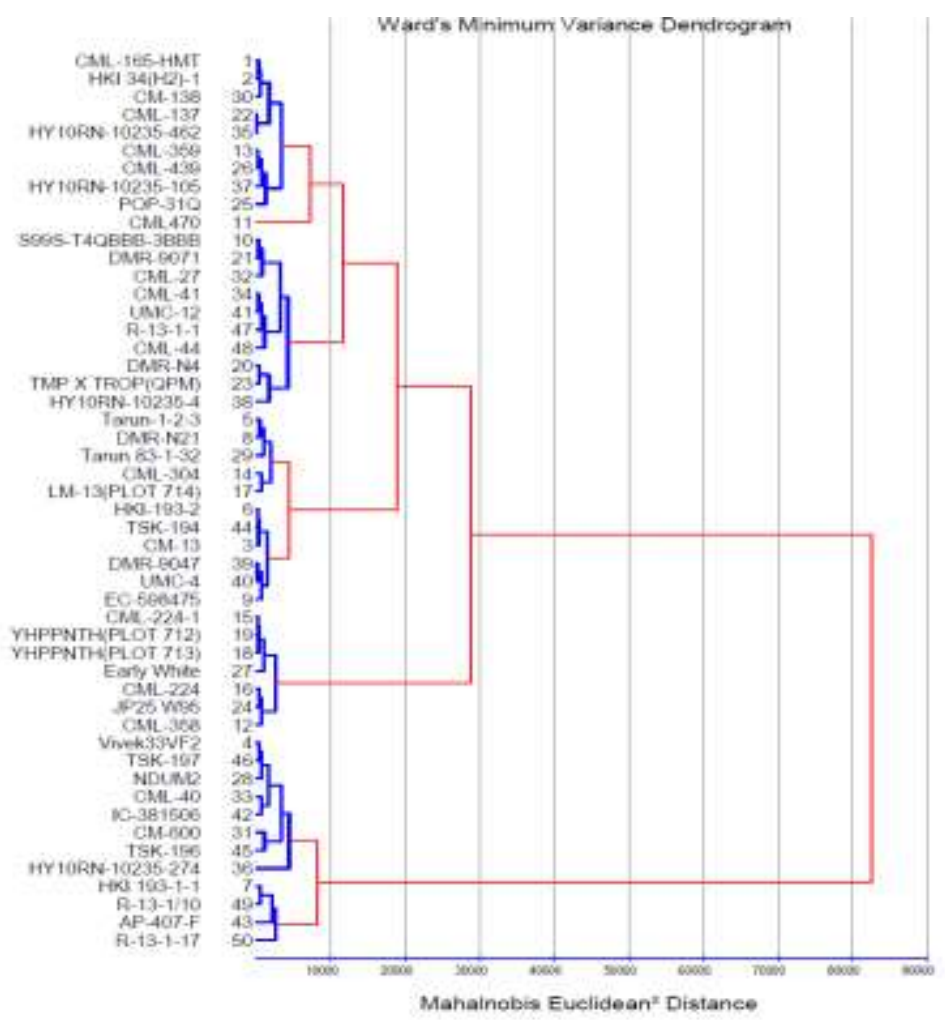

Figure.2. Mahalnobis Euclidean average linkage dendogram. 
Genetic Diversity Analysis in Sub-tropical Maize (Zea Mays L.) germplasm

Table 4.Cluster mean values of 8 clusters for different quantitative cluster in maize (Zea mays L).

\begin{tabular}{|c|c|c|c|c|c|c|c|c|c|c|c|c|c|c|c|c|}
\hline $\begin{array}{c}\text { Clust } \\
\text { ers }\end{array}$ & $\begin{array}{c}\text { Days to } \\
\mathbf{5 0 \%} \\
\text { Tasseling } \\
\text { (days) }\end{array}$ & $\begin{array}{c}\text { Days } \\
\text { to } 50 \\
\% \\
\text { Silking } \\
\text { (days) }\end{array}$ & $\begin{array}{l}\text { AnthesisS } \\
\text { illingInte } \\
\text { rval } \\
\text { (days) }\end{array}$ & $\begin{array}{c}\text { Seed fill } \\
\text { duration } \\
\text { (days) }\end{array}$ & $\begin{array}{l}\text { Plant } \\
\text { height } \\
\text { (cw) }\end{array}$ & $\begin{array}{l}\text { Ear } \\
\text { height } \\
(\mathrm{cm})\end{array}$ & $\begin{array}{c}\text { Number } \\
\text { of Cobs } \\
\text { per } \\
\text { plant }\end{array}$ & $\begin{array}{l}\text { Days to } \\
\text { maturity } \\
\text { (days) }\end{array}$ & $\begin{array}{c}\text { Ear } \\
\text { length } \\
(\mathrm{cm})\end{array}$ & $\begin{array}{l}\text { Ear } \\
\text { girth } \\
\text { (cm) }\end{array}$ & $\begin{array}{l}\text { Number } \\
\text { of grain } \\
\text { rows } \\
\text { per cob }\end{array}$ & $\begin{array}{c}\text { Number } \\
\text { of } \\
\text { grains } \\
\text { per } \\
\text { row }\end{array}$ & $\begin{array}{l}\text { Grain } \\
\text { yield } \\
\text { per } \\
\text { plant } \\
\text { (g) }\end{array}$ & $\begin{array}{c}100 \\
\text { seed } \\
\text { meight } \\
(\mathrm{g})\end{array}$ & $\begin{array}{c}\text { Leaf } \\
\text { area } \\
\text { per } \\
\text { plant } \\
\left(\mathrm{cm}^{2}\right)\end{array}$ & $\begin{array}{l}\text { Leaf } \\
\text { area } \\
\text { index }\end{array}$ \\
\hline I & 115.83 & 118.33 & 2.50 & 29.88 & 152.15 & 46.04 & 1.17 & 148.21 & 12.75 & 10.63 & 13.05 & 2293 & 44.65 & 20.00 & $6199 \Omega$ & 4.78 \\
\hline II & 106.33 & 10852 & 219 & 36.76 & 109.89 & 36.45 & 1.14 & 145.29 & 1101 & 9.30 & 12.38 & 1633 & 41.76 & 1834 & 394936 & 2.89 \\
\hline III & 101.67 & 103.67 & 2.00 & 41.00 & 119.03 & 3559 & 1.33 & 144.67 & 1135 & 9.85 & 12.22 & 19.39 & 49.82 & 18.64 & 272951 & 1.89 \\
\hline IV & 120.00 & 12267 & 2.67 & 3233 & 97.77 & $26.6 \mathrm{I}$ & 1.00 & 155.00 & 11.11 & 10.02 & 10.67 & 13.67 & 32.21 & 16.47 & 397097 & 293 \\
\hline $\mathrm{v}$ & 111.11 & 113.56 & 2.44 & 32.83 & 137,71 & 4475 & 1.22 & 146.39 & 12.00 & 1024 & 12.22 & 17.44 & 47.46 & 20.61 & 4546.08 & 3.40 \\
\hline VI & 113.15 & 115.41 & 2.26 & 32.70 & 17532 & 51.06 & 1.33 & 148.11 & 1439 & 11.72 & 13.11 & 27.13 & 46.63 & 20.67 & 7720.81 & 6.06 \\
\hline VII & 113.11 & 11556 & 2.44 & 31.89 & 188.05 & 65.46 & 1.22 & 147.44 & 12.87 & 1132 & 13.78 & 24.11 & 47.49 & 1999 & 8936.67 & 3.04 \\
\hline VIII & 11795 & 120.29 & 2.33 & 3038 & 130.03 & 3337 & 1.10 & 150.67 & 11.45 & 10.03 & 12.48 & 19.91 & 34.68 & 1654 & 5284,00 & 4.02 \\
\hline
\end{tabular}

